\title{
A Little Too Much: Cardiac Electrophysiological Effects of Elevated Inward Rectifying Current Carried by the $K_{I R} 2.1$ Ion Channel Protein
}

Marlieke G. Veldhuis, Yuan Ji, and Marcel A.G. van der Heyden

Department of Medical Physiology, Division of Heart and Lungs, University Medical Center Utrecht, Yalelaan 50, 3584 CM Utrecht, Netherlands

\begin{abstract}
Inward rectifier currents carried by $K_{I R} 2.1$ proteins have an important role in cardiac electrophysiology. Animal knock-outs and human loss-of-function mutation carriers experience cardiac pro-arrhythmia, but phenotypes are not confined to the heart since these channels are prominently expressed in many other organs and tissues. We here review the other end of the spectrum, in which gainof-function of the $K_{I R} 2.1$ carried $I_{K 1}$ results in action potential shortening in isolated cardiomyocytes, and $\mathrm{QT}$ shortening in animals and humans. Gain-of-function mutations in patients often result in short QT syndrome accompanied with atrial fibrillation. Remarkable, skeletal muscle, neurological and developmental abnormalities are less prominent in these patients compared to their loss-of-function counterparts. Finally, the most common pathological arrhythmia, atrial fibrillation, is associated with $K_{I R} 2.1$ upregulation at the mRNA and protein level, and concomitant enhanced $I_{K 1}$ density in atrial tissues.
\end{abstract}

Key Words: atrial fibrillation, drugs, $\mathrm{I}_{\mathrm{K} 1}, \mathrm{~K}_{\mathrm{IR}} 2.1$, short QT syndrome

\section{Introduction}

Action potential (AP) formation stands at the basis of cardiac contraction. The uneven distribution of sodium, potassium and calcium ions between the intraand extra-cellular compartment in concert with the presence of voltage sensitive and ion selective channels on the sarcolemma enables the cardiac myocyte to rapidly change its membrane potential and hence creating an AP. Between subsequent APs, potassium conductance resulting from inward rectifier channels formed by $\mathrm{K}_{\mathrm{IR}} 2$.x proteins, maintain a stable resting membrane potential (RMP) that lies close to the potassium reversal potential. Many basic science insights in the function of these $\mathrm{K}_{\mathrm{IR}} 2 . \mathrm{x}$ channels have been obtained from experimental models and human disease in which $\mathrm{K}_{\mathrm{IR}} 2$.x carried inward rectifier current $\left(\mathrm{I}_{\mathrm{K} 1}\right)$ is reduced. Very informative are the numerous studies on KCNJ2 mutations that result in $\mathrm{K}_{\mathrm{IR}} 2.1$ loss-of-function causing Andersen-Tawil syn- drome in men. Patients show a variety of clinical signs like periodic paralysis, cardiac arrhythmias and developmental abnormalities. Recently, this interesting field has been comprehensively reviewed (24). On the other side of the coin, we find gain-of-function studies that contribute necessary additional information on the role of this intriguing ion current on cardiac electrophysiology. As recently it was identified that particular drugs are able to cause increases in $\mathrm{K}_{\mathrm{IR}} 2.1$, whereas a very common cardiac arrhythmia, i.e. atrial fibrillation (AF), has been associated with enhanced $\mathrm{I}_{\mathrm{K} 1}$ function. This review therefore aims to overview the electrophysiological effects of increased $\mathrm{I}_{\mathrm{K} 1}$ in experimental models and by gain-of-function mutations leading to human disease.

\section{$K_{\text {IR }}$ Channel Properties}

$\mathrm{I}_{\mathrm{K} 1}$ has a pronounced influence on cardiac excitability and arrhythmogenesis (7). Potassium inward rectifier channels have a unique characteristic whereby they generate large $\mathrm{K}^{+}$current at potentials negative to the equilibrium potential of $\mathrm{K}^{+}\left(E_{\mathrm{K}}\right)(16)$. However at potentials positive to the $E_{\mathrm{K}}$ there is less current flow. This inward rectification of $\mathrm{K}^{+}$is due to intracellular $\mathrm{Mg}^{2+}$ and polyamines. They are able to physically block $\mathrm{K}^{+}$leaving the cell, by binding deep in the channel (27) interacting with the trans-membrane and cytoplasmic regions (16). $\mathrm{K}_{\mathrm{IR}}$ channels have a mutual structure consisting of two membrane-spanning domains (TM1 and TM2) linked together by a pore-forming region (H5), which protrudes back into the cell membrane (16). The amino and carboxyl-terminals are located in the intracellular region, the general structure is shown, with the $\mathrm{K}_{\mathrm{IR}} 2.1$ channel, in Fig. 1. Currently there are 15 known $K_{I R}$ subunits; they have been classified in to seven subfamilies, $\mathrm{K}_{\mathrm{IR}} 1 . \mathrm{x}$ to $\mathrm{K}_{\mathrm{IR}} 7 . \mathrm{x}$ (16). Sequence homology, between subfamily is $40 \%$, increasing to approximately $60 \%$ within subfamilies (5). In the heart numerous $\mathrm{K}_{\mathrm{IR}}$ channels have been identified, such as

Corresponding author: Dr. Marcel A.G. van der Heyden, Department of Medical Physiology, Division of Heart \& Lungs, Yalelaan 50, 3584 CM Utrecht, The Netherlands. Tel: +31 30 2538901, Fax: +3130 2539064, E-mail: m.a.g.vanderheyden@umutrecht.nl Received: December 19, 2014; Accepted: January 22, 2015.

(c)2015 by The Society of Adaptive Science in Taiwan and Airiti Press Inc. ISSN : 2076-944X. http://www.sast.org.tw 
Table 1. Drugs with $\mathrm{I}_{\mathrm{K} 1}$ increasing properties as off target effects

\begin{tabular}{llll}
\hline Compound & Main Effect & Dose-Effect Relation & Reference \\
\hline Flecainide & $\mathrm{Na}_{\mathrm{v}} 1.5$ Antagonist & $\mathrm{K}_{\mathrm{IR}} 2.1 \mathrm{EC}_{50}(-50 \mathrm{mV})=0.4 \pm 0.01 \mu \mathrm{M}$ & $(3)$ \\
& & $\mathrm{K}_{\mathrm{IR}} 2.1 \mathrm{EC}_{50}(-120 \mathrm{mV})=0.8 \pm 0.01 \mu \mathrm{M}$ & \\
& & $\mathrm{K}_{\mathrm{IR}} 2.1 \mathrm{E}_{\max }(-50 \mathrm{mV})=53.9 \pm 3.6 \%$ & \\
\hline Propafenone & $\mathrm{K}_{\mathrm{IR}} 2.1 \mathrm{E}_{\max }(-120 \mathrm{mV})=22 \pm 1.9 \%$ & \\
\hline Timolol & $\mathrm{Na}^{+}$Channel Antagonist & $\mathrm{K}_{\mathrm{IR}} 2.1 \mathrm{EC}_{50}(-50 \mathrm{mV})=12.0 \pm 3.0 \mathrm{nM}$ & $(14)$ \\
\hline Zacopride & & $\mathrm{K}_{\mathrm{IR}} 2.1 \mathrm{E}_{\max }(-50 \mathrm{mV})=42.0 \pm 2.6 \%$ & \\
& Non-Selective $\beta$-Antagonist & $\mathrm{K}_{\mathrm{IR}} 2.1 \mathrm{EC}_{50}(-50 \mathrm{mV})=3.2 \pm 0.3 \mathrm{nM}$ & $(14)$ \\
& 5-HT3 Antagonist & $\mathrm{K}_{\mathrm{IR}} 2.1 \mathrm{EC}_{50}(-50 \mathrm{mV})=30.7 \mu \mathrm{M}$ & $(20,37)$ \\
& 5-HT4 Agonist & $\mathrm{K}_{\mathrm{IR}} 2.1 \mathrm{E}_{\max }(-50 \mathrm{mV})=40.7 \pm 9.7 \%$ & \\
\hline
\end{tabular}

$\#_{a}$ study of Zacopride mediated activation of $\mathrm{I}_{\mathrm{K} 1}$ in attenuating ventricular remodeling following myocardial infarction by the same group contained data irregularities in Fig. 1 and Fig. 2, and has been retracted by the authors.

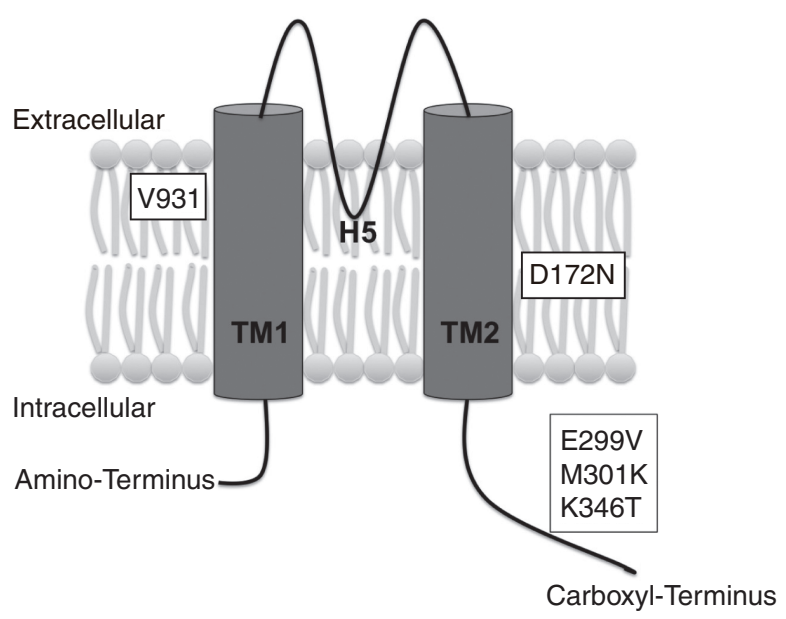

Fig. 1. Schematic representation of the $\mathrm{K}_{\mathrm{IR}} 2.1$ channel protein structure with the transmembrane regions 1 and 2 (TM1,2) and the pore-loop (H5) domain illustrated. Currently known gain-of-function mutations are depicted by single letter coding.

$\mathrm{K}_{\mathrm{IR}} 2.1, \mathrm{~K}_{\mathrm{IR}} 2.2, \mathrm{~K}_{\mathrm{IR}} 2.3, \mathrm{~K}_{\mathrm{IR}} 3.1, \mathrm{~K}_{\mathrm{IR}} 3.4, \mathrm{~K}_{\mathrm{IR}} 6.2$. These channels have varying rectifying strengths and locations where they are expressed (5). $\mathrm{I}_{\mathrm{K} 1}$ is crucial for shaping the cardiac AP for the following reasons. By adding to a negative RMP, it supports sodium channel availability in AP upstroke formation. Furthermore, its outward current component contributes significantly to the final phase of repolarization.

$\mathrm{I}_{\mathrm{K} 1}$ density, properties and expression of the underlying protein subunits differs between the atria and ventricle. In general, ventricular $\mathrm{I}_{\mathrm{K} 1}$ density is much higher (6-10 fold) than that of the atria (7). Ventricular $\mathrm{I}_{\mathrm{K} 1}$ channels are dominated by the presence of $\mathrm{K}_{\mathrm{IR}} 2.1$ subunits, whereas atrial $\mathrm{I}_{\mathrm{K} 1}$ results from more equal expression of $\mathrm{K}_{\mathrm{IR}} 2.1, \mathrm{~K}_{\mathrm{IR}} 2.2$ and $\mathrm{K}_{\mathrm{IR}} 2.3$ subunits (11). Here, we will focus on $\mathrm{K}_{\mathrm{IR}} 2.1$ channels, the highest expressed and best studied isoform in the heart. $\mathrm{K}_{\mathrm{IR}} 2.1$ becomes also expressed in many other tissues (5) and this is likely the basis for the pleiotropic phenotype as seen in patients with $K C N J 2$ loss-of-function mutations.

\section{Drugs that Increase $\mathbf{I}_{\mathrm{K} 1}$}

As there has been a lack of pharmacological tools to specifically enhance $I_{\mathrm{K} 1}$ it has been hard to decipher the role of $\mathrm{I}_{\mathrm{K} 1}$ up-regulation in cardiac excitability. However in recent years a number of drugs have been identified that increase $\mathrm{K}_{\mathrm{IR}} 2.1$ carried currents, albeit not specific for $\mathrm{I}_{\mathrm{K} 1}$, listed in Table 1. Drugs such as timolol and zacopride did show a decrease in action potential duration (APD) $(20,31)$, which would be expected with a $\mathrm{K}_{\mathrm{IR}} 2.1$ increase. Yet its source whether due to a primary mechanism of action or secondary effect, has not been deciphered yet. Caballero et al. (3) disscusses the potential role that $\mathrm{K}_{\mathrm{IR}} 2.1$, could have when flecainide is administered. Flecainide increases the effective refractory period (ERP) and prolongs the APD, which is more evident in the atrial cells compared to ventricular cells. Interestingly flecainide is shown to increase $\mathrm{I}_{\mathrm{K} 1}$ in ventricular myocytes and not in the atria. The authors suggest that the increase in $\mathrm{I}_{\mathrm{K} 1}$ can account for the differences seen in APD in ventricle versus atria (3). They speculate that the $\mathrm{I}_{\mathrm{K} 1}$ increase can overcome the effects of $\mathrm{I}_{\mathrm{Kr}}$ blockade on APD prolongation in ventricles. Additionally in the atrial cells, APD prolongation is evident due to blockade of $\mathrm{I}_{\mathrm{Kr}}$ without interference of increased $\mathrm{I}_{\mathrm{K} 1}$. Finally, whether $I_{\mathrm{K} 1}$ increase in ventricular myocytes could be a contributing factor to the ventricular pro- 
Table 2. Electrophysiological parameters in experimental models with increased $\mathbf{I}_{\mathrm{K} 1}$

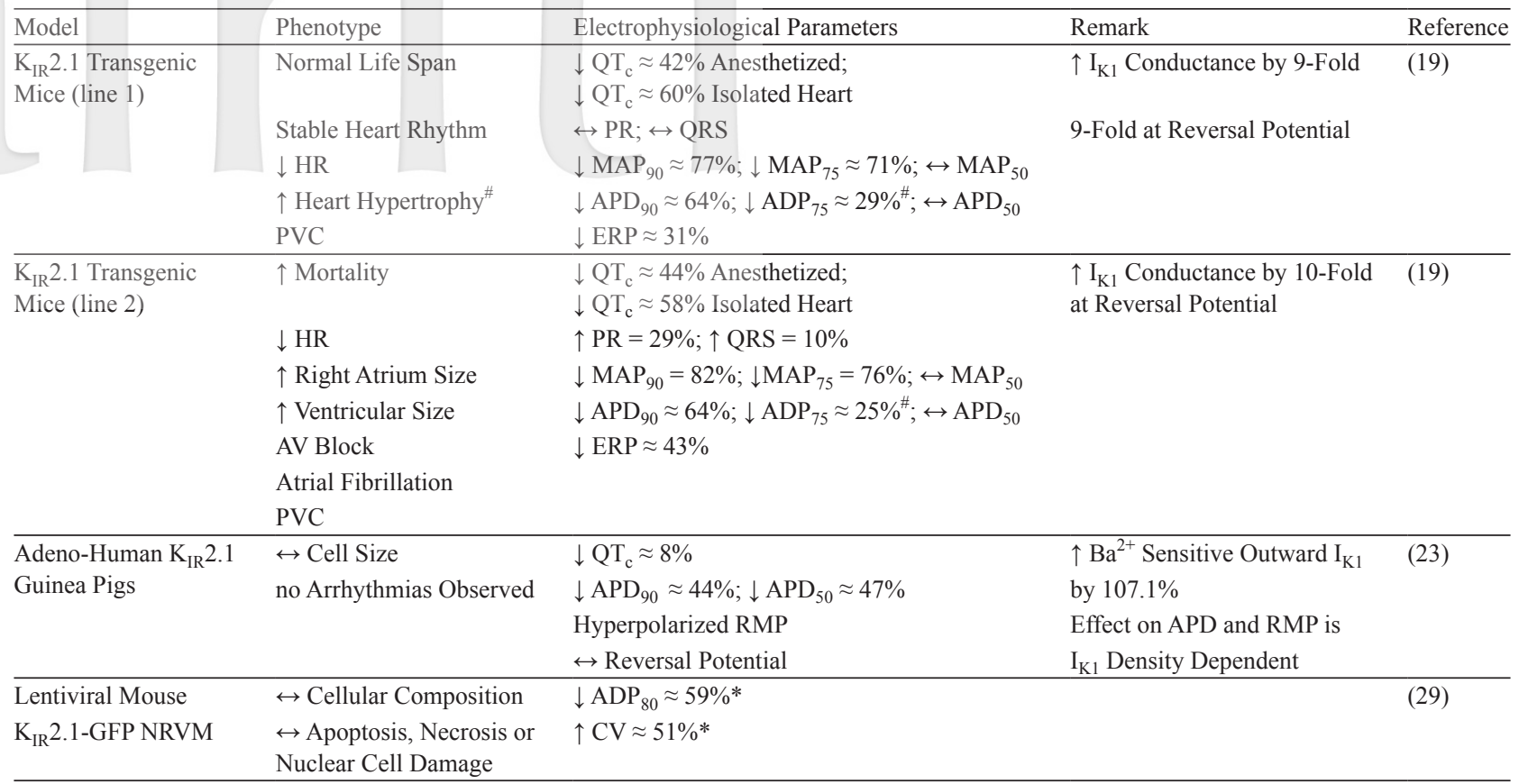

$\downarrow \mathrm{QT}_{\mathrm{c}} \approx 42 \%$ to be read as "a decrease in $\mathrm{QT}_{\mathrm{c}}$ by approximately $42 \%$ ". " non-significant. *compared with empty lentiviral vector. Abbreviations: $\mathrm{HR}$, heart rate; PVC, premature ventricular contraction; AV, atrial-ventricular; $\mathrm{QT}_{\mathrm{c}}$, rate corrected activation-repolarization time on electrocardiogram; PR, atrial-ventricular conduction time; QRS, ventricular activation time; APDx, action potential duration at $\mathrm{x} \%$ of maximal repolarization; MAPx, monophasic action potential duration at $\mathrm{x} \%$ of maximal repolarization; ERP, effective refractory period; CV, conduction velocity.

arrhythmic effects that are, although rarely, seen in flecainide remains to be studied further.

Since an increase in $\mathrm{K}_{\mathrm{IR}} 2.1$ can have both antiand pro-arrhythmic properties dependent on the underlying disease mechanism, it shows the importance of considering $\mathrm{I}_{\mathrm{K} 1}$ effects in drug development. However, the listed drugs do not further help with deciphering the role of $\mathrm{K}_{\mathrm{IR}} 2.1$ up-regulation on the cardiac electrophysiological properties. This is due to the vast amount of primary and secondary targets and, yet unknown side-effects, that these compounds have. Thus more specificity is needed, which can be established by molecular tools in experimental animal models.

\section{Molecular Tools to Upregulate $\mathbf{I}_{\mathbf{K} 1}$}

To date there are three successful methods in which $\mathrm{K}_{\mathrm{IR}} 2.1$ has been up-regulated in animal models/cells, highlighted in Table 2. Transgenic mice (line 1 and 2 ), adenovirus with human $\mathrm{K}_{\mathrm{IR}} 2.1$ in guinea pig and lentivirus cardiomyocyte model with mice $\mathrm{K}_{\mathrm{IR}} 2.1$ eGFP all display enhanced $\mathrm{I}_{\mathrm{K} 1}$ function. The data obtained from these animal and cell models gives a clear indication of the effect of $\mathrm{K}_{\mathrm{IR}} 2.1$ up-regulation on its electrophysiological parameters without many additional confounding variables. In all conditions there was a decrease in APD. Additionally there was a general decrease in QT interval, monophasic action potential duration (MAPD), and ERP. This is expected; as an overexpression of $\mathrm{K}_{\mathrm{IR}} 2.1$ would allow more of the positively charged potassium ions to exit the cell, thus decrease the APD. There was some variation between effects on $\mathrm{APD}_{50}$ as in transgenic mice there was no change and in guinea pigs injected with adenovirus there was a $47 \%$ decrease. As the $I_{K 1}$ densities between the two are comparable, it is believed this is due to the difference in AP morphology and the level of expression of the underlying ion channels between guinea pigs and mice. Hyperpolarization of the RMP was seen in adenovirus human- $\mathrm{K}_{\mathrm{IR}} 2.1$ treated guinea pigs, which reflects findings with gain-of-function patients $(6,18,26)$. An increase of conduction velocity (CV) was observed in the $\mathrm{K}_{\mathrm{IR}}$ 2.1-GFP neonatal rat ventricular cardiomyocytes, however it was not measured elsewhere and varies to that seen in gain-of-function patients (18). There were other ECG differences observed in the line 2 transgenic mice, i.e. increased PR and QRS intervals, that were not observed in line 1 mice which had a lower level of $\mathrm{I}_{\mathrm{K} 1}$ transgenic expression compared to line 2 mice. It is important to mention that Sekar et al. (29) found that eGFP had significant effects on neonatal rat ventricular myocytes showing a decrease in APD and CV, conflicting the belief that eGFP is physiologically inert. Thus for the transgenic mouse model that fused the GFP to the wild- 
Table 3. KCNJ2 gain-of-function mutations associated with human disease

\begin{tabular}{|c|c|c|c|c|}
\hline Mutation & Phenotype & Electrophysiological Parameters & Remark & Reference \\
\hline V93I & $\begin{array}{l}\text { Atrial Fibrillation } \\
\text { Normal QT } \\
\text { no Syncope } \\
\text { no Frequent PVC } \\
\text { no Frequent Ventricular Tachycardia } \\
\text { Normokalemic, no Muscle Weakness } \\
\text { no Developmental Abnormalities }\end{array}$ & $\begin{array}{l}\downarrow \mathrm{APD}_{90} 26 \% \text { Het; } \downarrow \mathrm{APD}_{90} 55 \% \text { Hom } \\
\downarrow \text { ERP } \\
\text { Hyperpolarized RMP } \\
\downarrow \mathrm{CV}=8 \% \text { Het; } \downarrow \mathrm{CV}=12 \% \text { Hom } \\
\downarrow \mathrm{I}_{\mathrm{Ca}-\mathrm{L}} \text { during the AP Plateau Phase } \\
\leftrightarrow \mathrm{I}_{\mathrm{Kur}}, \mathrm{I}_{\mathrm{Kr}} \text { and } \mathrm{I}_{\mathrm{Ks}} \\
\leftrightarrow \text { Intercellular Electrical Coupling }\end{array}$ & $\downarrow$ CV Due to Hyperpolarized RMP & $(18,35)$ \\
\hline $\mathrm{D} 172 \mathrm{~N}$ & $\begin{array}{l}\text { Short QT } \\
\text { Presyncopal Events } \\
\text { Palpitations } \\
\text { Rare Seizure Like Activities } \\
\text { Lamenting Tachycardia } \\
\text { no Developmental Abnormalities } \\
\text { no Muscle Disease }\end{array}$ & $\begin{array}{l}\downarrow \mathrm{QT}(315-320 \mathrm{~ms}) \\
\text { Narrow and Peaked T-Wave } \\
\downarrow \mathrm{APD} \approx 15 \% \text { Hom } \\
\text { Hyperpolarized RMP } \\
\uparrow \mathrm{Vmax} \\
\leftrightarrow \mathrm{CV}\end{array}$ & & (26) \\
\hline E299V & $\begin{array}{l}\text { Atrial Fibrillation } \\
\text { Short QT } \\
\text { Mild Left Ventricular Dysfunction } \\
\text { Reduced } \mathrm{EF}(\mathrm{EF} \approx 40 \%) \\
\text { no Ventricular Arrhythmias }\end{array}$ & $\begin{array}{l}\downarrow \text { QT }(200 \mathrm{~ms}) \\
\text { Peaked T-Wave } \\
\text { no Distinctive ST Segments } \\
\downarrow \mathrm{APD}_{80} 56 \% \text { Het; } \downarrow \mathrm{APD}_{80} 67 \% \text { Hom } \\
\text { Hyperpolarized RMP } \\
\uparrow \text { Vmax } \\
\leftrightarrow \mathrm{CV}\end{array}$ & & (6) \\
\hline M301K & $\begin{array}{l}\text { Atrial Fibrillation } \\
\text { Syncope } \\
\text { Sudden Death Due to Ventricular Tachyarrhythmia } \\
\text { no Structural Cardiac Abnormalities } \\
\text { Mental Retardation } \\
\text { Abnormal Oesophagal Blood Vessels } \\
\text { Epilepsy } \\
\text { Kawasaki Disease }\end{array}$ & $\begin{array}{l}\downarrow \mathrm{QT}(172 \mathrm{~ms}), \downarrow \mathrm{QT}_{\mathrm{c}}(194 \mathrm{~ms}) \\
\downarrow \mathrm{APD}_{90} \approx 67 \% \mathrm{Het}\end{array}$ & & (15) \\
\hline K346T & $\begin{array}{l}\text { Short QT } \\
\text { Intellectual Disabilities } \\
\text { Autism Spectrum Disorder } \\
\text { Infantile Spasm } \\
\text { Normokalemic }\end{array}$ & $\begin{array}{l}\downarrow \mathrm{QT}(275 \mathrm{~ms}) ; \downarrow \mathrm{QT}_{\mathrm{c}}(331 \mathrm{~ms}) \\
\text { Narrow and Peaked T-Wave }\end{array}$ & $\begin{array}{l}\text { In cis with a Gain-of-Function } \\
K C N J 10 \text { Mutation, Encoding the } \\
\mathrm{K}_{\mathrm{IR}} 4.1 \text { Channel }\end{array}$ & $(1,30)$ \\
\hline
\end{tabular}

Abbreviations: PVC, premature ventricular contraction; QT(c), (rate corrected) activation-repolarization time on electrocardiogram; APDx, action potential duration at $\mathrm{x} \%$ of maximal repolarization; ERP, effective refractory period; CV, conduction velocity; RMP, resting membrane potential; Het, heterozygous; Hom, homozygous; Vmax, maximal action potential upstroke velocity; EF, ejection fraction.

type $\mathrm{K}_{\mathrm{IR}} 2.1 \mathrm{cDNA}$ for both animal lines, it may have some influence on the observed APD decrease.

The up-regulation of the $\mathrm{K}_{\mathrm{IR}} 2.1$ channel in rodent animal models showed a general decrease in QT, APD, MAPD and ERP. Since the expression levels of the individual ion channel proteins that form the AP are different between rodents and humans, and hence result in a different AP morphologies between species, emphasis should be given on the role of $I_{K 1}$ channels in human cardiac electrophysiology. Very informative in this respect are the small number of human gain-of-function mutations in the $\mathrm{K}_{\mathrm{IR}} 2.1$ coding gene that has been identified and described together with the associated clinical phenotype.

\section{Human Gain-of-Function $K C N J 2$ Mutations Enhancing $\mathbf{I}_{\mathrm{K} 1}$}

In general, human $K C N J 2$ autosomal dominant gainof-function mutations are associated with the short QT syndrome Type 3 and AF (Table 3). These gain-offunction mutations are rare but can cause severe heart complications early on in life. The gain-of-function mutations can weaken the inward rectification, meaning more $\mathrm{I}_{\mathrm{KIR} 2.1}$ can be found at potentials positive to the $\mathrm{E}_{\mathrm{K}}$ as seen in the D172N, E299V and M301K mutations $(6,15,26)$. Studies in cell lines demonstrated that inhibition of normal $\mathrm{K}_{\mathrm{IR}} 2.1$ channel internalization and degradation results in increased levels of $\mathrm{K}_{\mathrm{IR}} 2.1$ protein expression and functional $\mathrm{I}_{\mathrm{K} 1}(17,33)$. Interestingly, the K346T mutation exhibited an increased $\mathrm{I}_{\mathrm{K} 1}$ amplitude of both the inward and outward component, and an impaired channel protein degradation may be at the basis of this finding (1). Remarkably, the V93I mutation can increase the activity of the $\mathrm{K}_{\mathrm{IR}} 2.1$ channel 
however does not display a decrease in QT interval (35).

Many of the gain-of-function mutations are associated with AF and brain disorders such as epilepsy and mental retardation. As $\mathrm{K}_{\mathrm{IR}} 2.1$ is also localized and involved in cell excitability in the brain, it is likely to account for the latter phenotype. There are many common electrophysiological parameters between the mutations, such as a decreased QT, APD and a hyperpolarized RMP. Conduction velocity seems to be unaffected, or slightly decreased due to the hyperpolarized RMP. This overlaps with the data obtained from the overexpressed $\mathrm{K}_{\mathrm{IR}} 2.1$ in rodent animal models. Interestingly, in many of the patients a narrowed and peaked, asymmetric T wave was observed in ECG recordings. Simulation studies provided evidence that this morphology may be due to a sudden acceleration of the final phase of repolarization which is caused by an increased contribution of outward potassium current by the mutant channels (26). While the V93I mutation did not associate with altered conduction in other potassium currents $\left(\mathrm{I}_{\mathrm{Kur}}, \mathrm{I}_{\mathrm{Kr}}\right.$ and $\left.\mathrm{I}_{\mathrm{Ks}}\right)$, there was a decreased L-type calcium current. This reduction can facilitate the shortening of the AP and the ERP (32).

Finally, whereas KCNJ2 loss-of-function mutations are often associated with periodic muscle paralysis and developmental abnormalities too, gain-of-function mutations appear to be less associated with these phenotypes.

\section{AF Associates with Increased Atrial $\mathbf{I}_{\mathrm{K} 1}$}

Approximately $23-26 \%$ of men and women above the age of 40 develop AF (21). Due to the irregular and uncoordinated, or even absence, of atrial contraction, clotting of the blood can occur and once released from within the diseased atria these cloths can cause stroke, lung embolization and myocardial infarction. Furthermore, the uncontrolled atrial activity results in non-regular ventricular activation and contraction, which on the long term can result in ventricular remodelling and heart failure. For these reasons, AF is strongly associated with stroke, heart failure, morbidity and increased mortality. The mechanisms underlying AF are multifactorial and can be classified into etiologic factors (heart disease, ageing, mutations) that cause atrial remodelling (structural, autonomic and electrical) which determines the electrophysiologic substrate enabling the two basic mechanisms driving AF initiation and perturbation (triggered activity and reentry) (28). In short, triggered activity arises from the occurrence of early and delayed after depolarizations (EADs, DADs) seen in the context of APD prolongation and aberrant sodium-calcium exchanger activity, respectively. Reentry mechanisms rely on ERP shortening (often concomitant with APD shortening), conduction
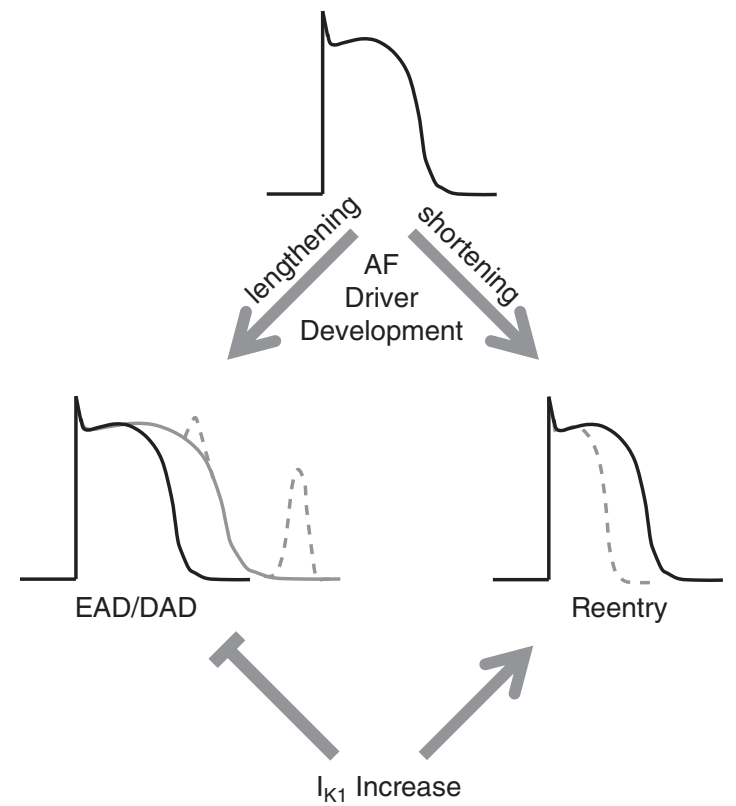

Fig. 2. Atrial AP lengthening promotes the occurrence of early and delayed afterpolarization (EAD/DAD) that may result in premature excitation. An increased $\mathrm{I}_{\mathrm{K} 1}$ density will inhibit this arrhythmic mechanism. AP shortening results in decreased effective refractory period of the atrial cell thereby promoting re-entry type arrhythmias. An increased $\mathrm{I}_{\mathrm{K} 1}$ density will promote this arrhythmic mechanism.

slowing or both (Fig. 2). As seen in the previous sections, an increased $\mathrm{I}_{\mathrm{K} 1}$ density is associated with AP shortening in experimental models and patients, and it is therefore no surprise that KCNJ2 gain-of-function mutations have been associated with AF as described in the previous section. Moreover, and from a general health perspective more relevant, a prominent and well documented feature of AF associated electrical remodelling is an increase in $\mathrm{I}_{\mathrm{K} 1}$, along with increased expression of the underlying KCNJ2 mRNA and $\mathrm{K}_{\mathrm{IR}} 2.1$ protein (Table 4).

AF has been correlated with altered microRNA expression, which in turn may be one of the causative factors for structural and electrical remodelling observed in the arrhythmic atrium. In a study on the influence of AF on microRNA expression in atrial tissue from valvular heart disease patients, it was found that 15 microRNAs were up-regulated and 32 were downregulated in the right atrial tissue from AF patients (4). Remarkably, no differences were found in left atrial tissue samples. Girmatsion (13) describes an inverse relation between microRNA-1 expression, an inhibitor of $\mathrm{K}_{\mathrm{IR}} 2.1$ expression (36), and $\mathrm{K}_{\mathrm{IR}} 2.1 \mathrm{mRNA}$, protein and $\mathrm{I}_{\mathrm{K} 1}$ in left atrial tissue samples from AF patients. This inverse relationship could however not be confirmed by Luo et al. (22) in their study using right atrial appendage material from AF patients. Instead, 
Table 4. Studies comparing human IK1 density and underlying proteins and transcripts in controls and AF

\begin{tabular}{lll}
\hline Number of subjects in study & Main findings in AF compared to controls & Reference \\
\hline 17 SR and 8 permanent AF & 3.4 -fold increase of outward $\mathrm{I}_{\mathrm{K} 1}($ at $-20 \mathrm{mV})$ & $(2)$ \\
& 2.0 -fold increase of inward $\mathrm{I}_{\mathrm{K} 1}($ at $-90 \mathrm{mV})$ & $(34)$ \\
\hline 39 SR and 11 permanent AF & 1.8 -fold increase of inward $\mathrm{I}_{\mathrm{K} 1}($ at $-115 \mathrm{mV})$ & $(9)$ \\
\hline 26 SR and 16 permanent AF & 1.7 -fold increase of inward $\mathrm{I}_{\mathrm{K} 1}($ at $-100 \mathrm{mV})$ & $(12)$ \\
\hline $7 \mathrm{SR}-\mathrm{VHD}$ and 11 AF-VHD & 1.9 -fold increase of inward $\mathrm{I}_{\mathrm{K} 1}($ at $-100 \mathrm{mV})$ & $(8)$ \\
& 1.8 -fold increase in $\mathrm{K}_{\mathrm{IR}} 2.1$ protein levels & $(13)$ \\
\hline 46 SR and 33 permanent AF & 1.9 -fold increase of inward $\mathrm{I}_{\mathrm{K} 1}($ at $-100 \mathrm{mV})$ & \\
& 1.2 -fold increase in $\mathrm{I}_{\mathrm{K} 1}$ open channel probability & \\
\hline $31 \mathrm{SR}$ and 31 persistent AF & 2.2 -fold increase of inward $\mathrm{I}_{\mathrm{K} 1}($ at $-100 \mathrm{mV})$ & \\
& 1.5 -fold increase in $\mathrm{K}_{\mathrm{IR}} 2.1$ protein levels & \\
& 0.9 -fold decrease in $\mathrm{K}_{\mathrm{IR}} 2.3$ protein levels & \\
& 3.0 -fold increase in $\mathrm{K}_{\mathrm{IR}} 2.1$ mRNA levels & $(22)$ \\
\hline $10 \mathrm{SR}$ and 12 AF & 0.2 -fold decrease in $\mathrm{K}_{\mathrm{IR}} 2.3$ mRNA levels & \\
\end{tabular}

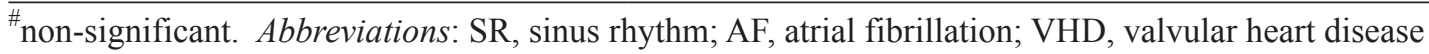

Luo et al. (22) found an inverse relationship between microRNA-26 and $\mathrm{K}_{\mathrm{IR}} 2.1$ mRNA and protein expression, and showed by applying a variety of molecular tools the causative relation between microRNA- 26 and $\mathrm{K}_{\mathrm{IR}} 2.1$ expression. Important to note is the fact that both microRNA-1 and microRNA-26 were not detected among the 47 differentially regulated microRNAs described by Cooley (4). Apparently, $\mathrm{K}_{\mathrm{IR}} 2.1$ regulation by microRNAs is complex and many additional studies are essential to shine light on these intriguing relationships.

\section{Correcting Increased $\mathrm{I}_{\mathrm{K} 1}$ by Pharmacological Agents}

Short QT and AF are the main symptoms of $\mathrm{I}_{\mathrm{K} 1}$ gain-offunction in patients. Although the number of patients with a monogenetic $\mathrm{K}_{\mathrm{IR}} 2.1$ gain-of-function is rather small, they may benefit from specific $\mathrm{I}_{\mathrm{K} 1}$ inhibiting drugs. The largest group of patients that may benefit from $\mathrm{I}_{\mathrm{K} 1}$ inhibition can be found in those with persistent and longstanding persistent $\mathrm{AF}$ associated with $\mathrm{I}_{\mathrm{K} 1}$ upregulation as described above. Indeed, chloroquine that shows $\mathrm{I}_{\mathrm{K} 1}, \mathrm{I}_{\mathrm{KAch}}$ and $\mathrm{I}_{\mathrm{KATP}}$ inhibiting capacity, is able to terminate both cholinergic AF and stretch induced $\mathrm{AF}$ in the isolated sheep heart $(10,25)$. For now, more specific $\mathrm{I}_{\mathrm{K} 1}$ inhibiting compounds are required to determine the contribution of enhanced $\mathrm{I}_{\mathrm{K} 1}$ in cardiac arrhythmias and to treat those that largely rely on enhanced $\mathrm{I}_{\mathrm{K} 1}$ as the underlying pathological cause.

\section{Conclusion}

Recently it was discovered that timolol, flecainide, propafenone and zacropride increase $\mathrm{I}_{\mathrm{K} 1}$. Rodent animal studies and human monogenetic disease show high consensus and strongly demonstrate the role of $\mathrm{K}_{\mathrm{IR}} 2.1$ carried $\mathrm{I}_{\mathrm{K} 1}$ in cardiac electrophysiology. In particular, APD and its derivatives MAPD and QT, are sensitive for $I_{K 1}$ increases. RMP values appear to be less affected by $\mathrm{I}_{\mathrm{K} 1}$ enhancement. Furthermore, spontaneous ventricular arrhythmias are rarely associated with increased $\mathrm{I}_{\mathrm{K} 1}$ density, whereas short QT syndrome and AF strongly correlate with $\mathrm{K}_{\mathrm{IR}} 2.1$ gain-of-function. Acquired AF strongly associates with increased $\mathrm{I}_{\mathrm{K} 1}$, although the underlying cause-effect relationships are still unclear. Partial reduction of $\mathrm{I}_{\mathrm{K} 1}$ in human disease like short QT syndrome and AF may be beneficial for patients.

\section{Acknowledgments}

Y.J. is the recipient of a scholarship from the Chinese Scholarship Council.

\section{References}

1. Ambrosini, E., Sicca, F., Brignone, M.S., D’Adamo, M.C., Napolitano, C., Servettini, I., Moro, F., Ruan, Y., Guglielmi, L., Pieroni, S., Servillo, G., Lanciotti, A., Valvo, G., Catacuzzeno, L., Franciolini, F., Molinari, P., Marchese, M., Grottesi, A., Guerrini, R., Santorelli, F.M., Priori. S. and Pessia, M. Genetically induced dysfunctions of Kir2.1 channels: implications for short QT3 syndrome and autism-epilepsy phenotype. Hum. Mol. Genet. 23: 4875-4886, 2014.

2. Bosch, R.F., Zeng, X., Grammer, J.B., Popovic, K., Mewis, C. and Kühlkamp, V. Ionic mechanisms of electrical remodeling in human atrial fibrillation. Cardiovasc. Res. 44: 121-131, 1999.

3. Caballero, R., Dolz-Gaitón, P., Gómez, R., Amorós, I., Barana, A., González de la Fuente, M., Osuna, L., Duarte, J., López-Izquierdo, 
A., Moraleda, I., Gálvez, E., Sánchez-Chapula, J.A., Tamargo, J. and Delpón, E. Flecainide increases Kir2.1 currents by interacting with cysteine 311 , decreasing the polyamine-induced rectification. Proc. Natl. Acad. Sci. USA 107: 15631-15636, 2010.

4. Cooley, N., Cowley, M.J., Lin, R.C., Marasco, S., Wong, C., Kaye, D.M., Dart, A.M. and Woodcock, E.A. Influence of atrial fibrillation on microRNA expression profiles in left and right atria from patients with valvular heart disease. Physiol. Genomics 44: 211219, 2012.

5. De Boer, T.P., Houtman, M.J., Compier, M. and van der Heyden, M.A. The mammalian $\mathrm{K}_{\mathrm{IR}} 2$.x inward rectifier ion channel family: expression pattern and pathophysiology. Acta Physiol. (Oxf). 199: 243-256, 2010.

6. Deo, M., Ruan, Y., Pandit, S.V., Shah, K., Berenfeld, O., Blaufox, A., Cerrone, M., Noujaim, S.F., Denegri, M., Jalife, J. and Priori, S.G. $K C N J 2$ mutation in short QT syndrome 3 results in atrial fibrillation and ventricular proarrhythmia. Proc. Natl. Acad. Sci. USA 110: 4291-4296, 2013.

7. Dhamoon, A.S. and Jalife, J. The inward rectifier current $\left(\mathrm{I}_{\mathrm{K} 1}\right)$ controls cardiac excitability and is involved in arrhythmogenesis. Heart Rhythm. 2: 316-324, 2005.

8. Dobrev, D., Friedrich, A., Voigt, N., Jost, N., Wettwer. E., Christ, T., Knaut, M. and Ravens, U. The G protein-gated potassium current $\mathrm{I}_{\mathrm{K}, \mathrm{ACh}}$ is constitutively active in patients with chronic atrial fibrillation. Circulation 112: 3697-3706, 2005.

9. Dobrev, D., Wettwer, E., Kortner, A., Knaut, M., Schüler, S. and Ravens, U. Human inward rectifier potassium channels in chronic and postoperative atrial fibrillation. Cardiovasc. Res. 54: 397-404, 2002.

10. Filgueiras-Rama, D., Martins, R.P., Mironov, S., Yamazaki, M., Calvo, C.J., Ennis, S.R., Bandaru, K., Noujaim, S.F., Kalifa, J., Berenfeld, O. and Jalife, J. Chloroquine terminates stretch-induced atrial fibrillation more effectively than flecainide in the sheep heart. Circ. Arrhythm. Electrophysiol. 5: 561-570, 2012.

11. Gaborit, N., Le Bouter, S., Szuts, V., Varro, A., Escande, D., Nattel, S. and Demolombe, S. Regional and tissue specific transcript signatures of ion channel genes in the non-diseased human heart. $J$. Physiol. 582: 675-693, 2007.

12. Gaborit, N., Steenman, M., Lamirault, G., Le Meur, N., Le Bouter, S., Lande, G., Léger, J., Charpentier, F., Christ, T., Dobrev, D., Escande, D., Nattel, S. and Demolombe, S. Human atrial ion channel and transporter subunit gene-expression remodeling associated with valvular heart disease and atrial fibrillation. Circulation 112: 471481, 2005.

13. Girmatsion, Z., Biliczki, P., Bonauer, A., Wimmer-Greinecker, G., Scherer, M., Moritz, A., Bukowska, A., Goette, A., Nattel, S., Hohnloser, S.H. and Ehrlich, J.R. Changes in microRNA-1 expression and $\mathrm{I}_{\mathrm{K} 1}$ up-regulation in human atrial fibrillation. Heart Rhythm 6: 1802-1809, 2009.

14. Gómez, R., Caballero, R., Barana, A., Amorós, I., De Palm, S.H., Matamoros, M., Núñez, M., Pérez-Hernández, M., Iriepa, I., Tamargo, J. and Delpón, E. Structural basis of drugs that increase cardiac inward rectifier Kir2.1 currents. Cardiovasc. Res. 104: 337-346, 2014.

15. Hattori, T., Makiyama, T., Akao, M., Ehara, E., Ohno, S., Iguchi, M., Nishio, Y., Sasaki, K., Itoh, H., Yokode, M., Kita, T., Horie, M. and Kimura, T. A novel gain-of-function KCNJ2 mutation associated with short-QT syndrome impairs inward rectification of Kir2.1 currents. Cardiovasc. Res. 93: 666-673, 2012.

16. Hibino, H., Inanobe, A., Furutani, K., Murakami, S., Findlay, I. and Kurachi, Y. Inwardly rectifying potassium channels: their structure, function, and physiological roles. Physiol. Rev. 90: 291-366, 2010.

17. Jansen, J.A., de Boer, T.P., Wolswinkel, R., van Veen, T.A., Vos, M.A., van Rijen, H.V. and van der Heyden, M.A. Lysosome mediated Kir2.1 breakdown directly influences inward rectifier current density. Biochem. Biophys. Res. Commun. 367: 687-692, 2008.

18. Kharche, S., Garratt, C.J., Boyett, M.R., Inada, S., Holden, A.V.,
Hancox, J.C. and Zhang, H. Atrial proarrhythmia due to increased inward rectifier current $\left(I_{\mathrm{K} 1}\right)$ arising from $K C N J 2$ mutation-a simulation study. Prog. Biophys. Mol. Biol. 98: 186-197, 2008.

19. Li, J., McLerie, M. and Lopatin, A.N. Transgenic upregulation of $I_{\mathrm{K} 1}$ in the mouse heart leads to multiple abnormalities of cardiac excitability. Am. J. Physiol. Heart Circ. Physiol. 287: H2790-H2802, 2004.

20. Liu, Q.H., Li, X.L., Xu, Y.W., Lin, Y.Y., Cao, J.M. and Wu, B.W. A novel discovery of IK1 channel agonist: zacopride selectively enhances IK1 current and suppresses triggered arrhythmias in the rat. J. Cardiovasc. Pharmacol. 59: 37-48, 2012.

21. Lloyd-Jones, D.M., Wang, T.J., Leip, E.P., Larson, M.G., Levy, D., Vasan, R.S., D’Agostino, R.B., Massaro, J.M., Beiser, A., Wolf, P.A. and Benjamin, E.J. Lifetime risk for development of atrial fibrillation: the framingham heart study. Circulation 110: 1042-1046, 2004.

22. Luo, X., Pan, Z., Shan, H., Xiao, J., Sun, X., Wang, N., Lin, H., Xiao, L., Maguy, A., Qi, X.Y., Li, Y., Gao, X., Dong, D., Zhang, Y., Bai, Y., Ai, J., Sun, L., Lu, H., Luo, X.Y., Wang, Z., Lu, Y., Yang, B. and Nattel, S. MicroRNA-26 governs profibrillatory inwardrectifier potassium current changes in atrial fibrillation. J. Clin. Invest. 123: 1939-1951, 2013.

23. Miake, J., Marbán, E. and Nuss, H.B. Functional role of inward rectifier current in heart probed by Kir2.1 overexpression and dominant-negative suppression. J. Clin. Invest. 111: 1529-1536, 2003.

24. Nguyen, H.L., Pieper, G.H. and Wilders, R. Andersen-Tawil syndrome: clinical and molecular aspects. Int. J. Cardiol. 170: 1-16, 2013.

25. Noujaim, S.F., Stuckey, J.A., Ponce-Balbuena, D., Ferrer-Villada, T., López-Izquierdo, A., Pandit, S., Calvo, C.J., Grzeda, K.R., Berenfeld, O., Chapula, J.A. and Jalife, J. Specific residues of the cytoplasmic domains of cardiac inward rectifier potassium channels are effective antifibrillatory targets. FASEB J. 24: 4302-4312, 2010.

26. Priori, S.G., Pandit, S.V., Rivolta, I., Berenfeld, O., Ronchetti, E., Dhamoon, A., Napolitano, C., Anumonwo, J., di Barletta, M.R., Gudapakkam, S., Bosi, G., Stramba-Badiale, M. and Jalife, J. A novel form of short QT syndrome (SQT3) is caused by a mutation in the KCNJ2 gene. Circ. Res. 96: 800-807, 2005.

27. Rodriguez-Menchaca, A.A., Navarro-Polanco, R.A., Ferrer-Villada, T., Rupp, J., Sachse, F.B., Tristani-Firouzi, M. and Sánchez-Chapula, J.A. The molecular basis of chloroquine block of the inward rectifier Kir2.1 channel. Proc. Natl. Acad. Sci. USA 105: 1364-1368, 2008.

28. Schotten, U., Verheule, S., Kirchhof, P. and Goette, A. Pathophysiological mechanisms of atrial fibrillation: a translational appraisal. Physiol. Rev. 91: 265-325, 2011.

29. Sekar, R.B., Kizana, E., Smith, R.R., Barth, A.S., Zhang, Y., Marbán, E. and Tung, L. Lentiviral vector-mediated expression of GFP or Kir2.1 alters the electrophysiology of neonatal rat ventricular myocytes without inducing cytotoxicity. Am. J. Physiol. Heart Circ. Physiol. 293: H2757-H2770, 2007.

30. Sicca, F, Imbrici, P., D’Adamo, M.C., Moro, F., Bonatti, F., Brovedani, P., Grottesi, A., Guerrini, R., Masi, G., Santorelli, F.M. and Pessia, M. Autism with seizures and intellectual disability: possible causative role of gain-of-function of the inwardly-rectifying $\mathrm{K}^{+}$ channel Kir4.1. Neurobiol. Dis. 43: 239-247, 2011.

31. Tuncay, E., Seymen, A.A., Sam, P., Gurdal, H. and Turan, B. Effects of $\beta$-adrenergic receptor blockers on cardiac function: a comparative study in male versus female rats. Can. J. Physiol. Pharmacol. 87: 310-317, 2009.

32. Van Wagoner, D.R. Electrophysiological remodeling in human atrial fibrillation. Pacing Clin. Electrophysiol. 26: 1572-1575, 2003.

33. Varkevisser, R., Houtman, M.J., Waasdorp, M., Man, J.C., Heukers, R., Takanari, H., Tieland, R.G., van Bergen En Henegouwen, P.M., Vos, M.A. and van der Heyden, M.A. Inhibiting the clathrinmediated endocytosis pathway rescues $\mathrm{K}_{\mathrm{IR}} 2.1$ downregulation by pentamidine. Pflugers Arch. 465: 247-259, 2013. 
34. Workman, A.J., Kane, K.A. and Rankin, A.C. The contribution of ionic currents to changes in refractoriness of human atrial myocytes associated with chronic atrial fibrillation. Cardiovasc. Res. 52: 226-235, 2001.

35. Xia, M., Jin, Q., Bendahhou, S., He, Y., Larroque, M.M., Chen, Y., Zhou, Q., Yang, Y., Liu, Y., Liu, B., Zhu, Q., Zhou, Y., Lin, J., Liang, B., Li, L., Dong, X., Pan, Z., Wang, R., Wan, H., Qiu, W., Xu, W., Eurlings, P., Barhanin, J. and Chen, Y. A Kir2.1 gain-of-function mutation underlies familial atrial fibrillation. Biochem. Biophys.
Res. Commun. 332: 1012-1019, 2005.

36. Yang, B., Lin, H., Xiao, J., Lu, Y., Luo, X., Li, B., Zhang, Y., Xu, C., Bai, Y., Wang, H., Chen, G. and Wang, Z. The muscle specific microRNA miR-1 regulates cardiac arrhythmogenic potential by targeting GJA1 and KCNJ2. Nat. Med. 13: 486-491, 2007.

37. Zhang, L., Liu, Q., Liu, C., Zhai, X., Feng, Q., Xu, R., Cui, X., Zhao, Z., Cao, J. and Wu, B. Zacopride selectively activates the Kir2.1 channel via a PKA signaling pathway in rat cardiomyocytes. Sci. China Life Sci. 56: 788-796, 2013. 